\title{
Cytochemical profile of B and T leukaemic lymphocytes with special reference to acute lymphoblastic leukaemia
}

\author{
D. CAtovsky, J. Galetto, A. OKOS, E. Miliani, AND D. A. G. GAlton \\ From the MRC Leukaemia Unit, Royal Postgraduate Medical School, London
}

SYNOPSIS The PAS and acid phosphatase reactions showed a different pattern of positivity in the cells of lymphoproliferative disorders according to their B or T cell nature. In B-cell leukaemias (chronic lymphocytic and prolymphocytic) a low proportion of lymphocytes gave a positive result with the acid phosphatase reaction, while the majority were PAS positive in granular form. In contrast, in the T-prolymphocytic and T-lymphoblastic leukaemias the acid phosphatase reaction was positive in the majority of cells, while the PAS reaction was only positive in a minority. The significance of these findings, particularly for the recognition of a distinct T-cell variant of acute lymphoblastic leukaemia, is discussed.

The existence of two distinct populations of lymphocytes, $T$ (thymus-derived) and $B$ (bone marrowderived), has now been widely accepted. The distinction between these two cell types can be made accurately by means of immunological techniques (Transplantation Reviews, 1973). Differences in their surface structure as seen by scanning electron microscopy (Polliack, Lampen, Clarkson, De Harven, Bentwich, Siegal, and Kunkel, 1973) and their surface membranes (Mehrishi and Zeiller, 1974) have been demonstrated with specialized techniques. No clear differences have been recognized, however, by light or transmission electron microscopy. We have used two cytochemical methods (PAS and acid phosphatase) which showed markedly different appearances in B and $T$ leukaemic lymphocytes. These methods may help in the investigation of lymphoproliferative disorders, especially when cell suspensions cannot easily be obtained for immunological studies.

\section{Materials and Methods}

The cytochemical methods for PAS (Dacie and Lewis, 1970) and acid phosphatase (Goldberg and Barka, 1962) were applied to films made from the peripheral blood, buffy coats, and/or bone marrow from eight patients with chronic lymphocytic leukaemia, three with prolymphocytic leukaemia,

Received for publication 28 June 1974. and seven with acute lymphoblastic leukaemia. Prolymphocytic leukaemia is a rare variant of chronic lymphocytic leukaemia with distinct clinical, haematological, and cytological features (Galton, Goldman, Wiltshaw, Catovsky, Henry, and Goldenberg, 1974). The acid phosphatase reaction was also carried out in the presence of $0.05 \mathrm{M} \mathrm{L}(+)$ tartaric acid (Yam, Li, and Lam, 1971). The percentage of positive cells with both cytochemical reactions was assessed by examining a minimum of 200 cells. All the chronic and prolymphocytic leukaemia patients were untreated and had high leucocyte counts.

The clinical and laboratory data of the seven cases of acute lymphoblastic leukaemia are given in table $\mathbf{I}$. Cases 1, 3, and 4 were studied at diagnosis and the rest during a relapse; all of them had numerous blast cells in the blood and/or bone marrow at the time of our study. Cases 1 and 2 are reported in detail elsewhere (Catovsky, Goldman, Okos, Frisch, and Galton, 1974). Lymphoid cells from all the patients were examined for the presence of $B$ and $T$ cell markers:

B-CELL MARKERS

Surface-bound immunoglobulins by means of a direct immunofluorescence technique (Papamichail, Brown, and Holborow, 1971), with fluoresceinconjugated commercial antisera for the heavy chains of IgG, IgM, IgA, and IgD; Fc receptor by means of the aggregated $\gamma$-globulin indirect fluorescence technique of Dickler and Kunkel (1972); $C_{3}$ receptors 


\begin{tabular}{|c|c|c|c|c|c|c|c|c|c|}
\hline \multirow{3}{*}{$\begin{array}{l}\text { Case } \\
\text { No. }\end{array}$} & \multirow[t]{3}{*}{ Sex/Age } & \multicolumn{4}{|l|}{ Presenting Features } & \multirow{3}{*}{$\begin{array}{l}\text { CNS } \\
\text { Leukaemia }\end{array}$} & \multirow{3}{*}{$\begin{array}{l}\text { Cell } \\
\text { Type }\end{array}$} & \multirow{2}{*}{\multicolumn{2}{|c|}{$\begin{array}{l}\text { Cytochemical Profile } \\
\text { (\% positive blast cells) }\end{array}$}} \\
\hline & & $W B C / \mu l(\%$ blasts $)$ & Spleen $^{1}$ & Lymph Nodes & Anterior & & & & \\
\hline & & & $(\mathrm{cm})$ & Prominent & Mediastinal Mass & & & PAS & $\begin{array}{l}\text { Acid Phos- } \\
\text { phatase }\end{array}$ \\
\hline $\begin{array}{l}1 \\
2 \\
3\end{array}$ & $\begin{array}{l}M / 14 \\
M / 30 \\
F / 8\end{array}$ & $\begin{array}{r}1004000(95) \\
170000(93) \\
221000(99)\end{array}$ & $\frac{6}{15}$ & $\begin{array}{l}- \\
+ \\
+\end{array}$ & $\overline{-}$ & $\begin{array}{l}\text { Yes }(3 \mathrm{mth})^{2} \\
\text { Yes }(6 \mathrm{mth})^{2} \\
\text { No }\end{array}$ & $\begin{array}{l}\mathbf{T} \\
\mathbf{T} \\
\mathbf{T}\end{array}$ & $\begin{array}{r}30 \\
5 \\
1\end{array}$ & $\begin{array}{l}95 \\
90 \\
99\end{array}$ \\
\hline $\begin{array}{l}4 \\
5 \\
6 \\
7\end{array}$ & $\begin{array}{l}M / 26 \\
M / 5 \\
F / 3 \\
M / 16\end{array}$ & $\begin{array}{c}71600(94) \\
10500(50) \\
2400(46) \\
4000(0)\end{array}$ & $\begin{array}{l}2 \\
- \\
-\end{array}$ & $\begin{array}{l}- \\
-\end{array}$ & $\begin{array}{l}- \\
-\end{array}$ & $\begin{array}{l}\text { No } \\
\text { No } \\
\text { No } \\
\text { No }\end{array}$ & $\begin{array}{l}\text { Non-T } \\
\text { Non-T } \\
\text { Non-T } \\
\text { Non-T }\end{array}$ & $\begin{array}{l}44 \\
98 \\
55 \\
84\end{array}$ & $\begin{array}{l}\text { Not done } \\
0 \\
23 \\
1\end{array}$ \\
\hline
\end{tabular}

Table I Clinical and laboratory data in seven cases of acute lymphoblastic leukaemia

${ }^{1}$ Centimetres below the left costal margin.

'Time after diagnosis.

by means of ox red cells coated with an anti-ox red cell IgM antibody and complement (Pepys and Butterworth, in press).

\section{T-CELL MARKERS}

Spontaneous rosette formation with sheep red cells was according to Wybran, Chantler, and Fudenberg (1973). Transformation with phytohaemagglutinin (PHA) after three days' suspension culture was also examined in four cases of chronic lymphocytic leukaemia, three of prolymphocytic leukaemia, and two of acute lymphoblastic leukaemia, and assessed by morphology and ${ }^{3} \mathrm{H}$-thymidine incorporation.

\section{Results}

These are summarized in table II. The cells of all eight cases of chronic lymphocytic leukaemia and two of prolymphocytic leukaemia had B-cell features, while those of one of the latter and three cases of acute lymphoblastic leukaemia had T-cell markers. One of the patients with acute lymphoblastic leukaemia (case 3) who presented with an anterior mediastinal mass (table I) was considered of T-cell

\begin{tabular}{|c|c|c|c|}
\hline Leukaemia & $\begin{array}{l}\text { Number of } \\
\text { Cases Studied }\end{array}$ & $\begin{array}{l}\text { Acid } \\
\text { Phosphatase }\end{array}$ & $P A S$ \\
\hline $\begin{array}{l}\text { B-cell type } \\
\text { Chronic lymphocytic } \\
\text { Prolymphocytic }\end{array}$ & $\begin{array}{l}8 \\
2\end{array}$ & $\begin{array}{c}5-25 \% \\
10-15 \%^{1}\end{array}$ & $\begin{array}{l}80-95 \% \\
95 \%\end{array}$ \\
\hline $\begin{array}{l}T \text {-cell type } \\
\text { Prolymphocytic } \\
\text { Lymphoblastic }\end{array}$ & $\begin{array}{l}1 \\
3\end{array}$ & $\begin{array}{l}100 \% \\
90-99 \%\end{array}$ & $\begin{array}{l}7 \% \\
1-30 \%\end{array}$ \\
\hline $\begin{array}{l}\text { Lymphoblastic (non-T; } \\
\text { negative markers }\end{array}$ & 4 & $0-23 \%$ & $44-98 \%$ \\
\hline
\end{tabular}

Table II Percentage of positive cells in the different types of lymphoid leukaemia

'Half were tartaric acid resistant. type, despite a negative rosette formation with sheep red cells, because the leukaemic cells showed a significant response to PHA (transformation index: 11.6) and morphological changes consistent with PHA stimulation. Rosette formation in the other two T-cell cases of acute lymphoblastic leukaemia was seen in $65 \%$ (case 1) and $60 \%$ of the blast cells (case 2); the cells of case 1 did not show ${ }^{3} \mathrm{H}$-thymidine uptake or transformation when cultured with PHA. A significant response to PHA was also observed in the only case of T-cell prolymphocytic leukaemia, whilst the results were low or negative in four cases of chronic lymphocytic leukaemia and? the two B-cell cases of prolymphocytic leukaemia. Four patients with acute lymphoblastic leukaemia lacked both B- and T-cell markers (non-T type; table I).

The acid phosphatase reaction was weak or moderately positive in a small proportion of leukaemic B-cells, whilst it was moderately to strongly positive in the great majority of leukaemic T-cells; in all the cases the reaction product was localized in a small paranuclear area (fig 1, A and B). Half of the acid phosphatase-positive lymphocytes in the two B-cell cases of prolymphocytic leukaemia retained their positivity in the presence of $L(+)$ tartaric acid. All the B-cell leukaemias showed a positive PAS reaction in the form of fine to mediumsize cytoplasmic granules in 80 to $95 \%$ of the cells. The cells from the two B-cell patients with prolymphocytic leukaemia showed much coarser deposits of PAS-positive material than the cells from those with chronic lymphocytic leukaemia (fig 2, B). In contrast, in the T-cell leukaemias, the reaction was weak (fig 2, A) and affected a smaller proportion of lymphoid cells (table II). The cells from the non-T cases of acute lymphoblastic leukaemia showed a negative acid phosphatase reaction in two and $23 \%$ of moderately positive blasts in another, while the 


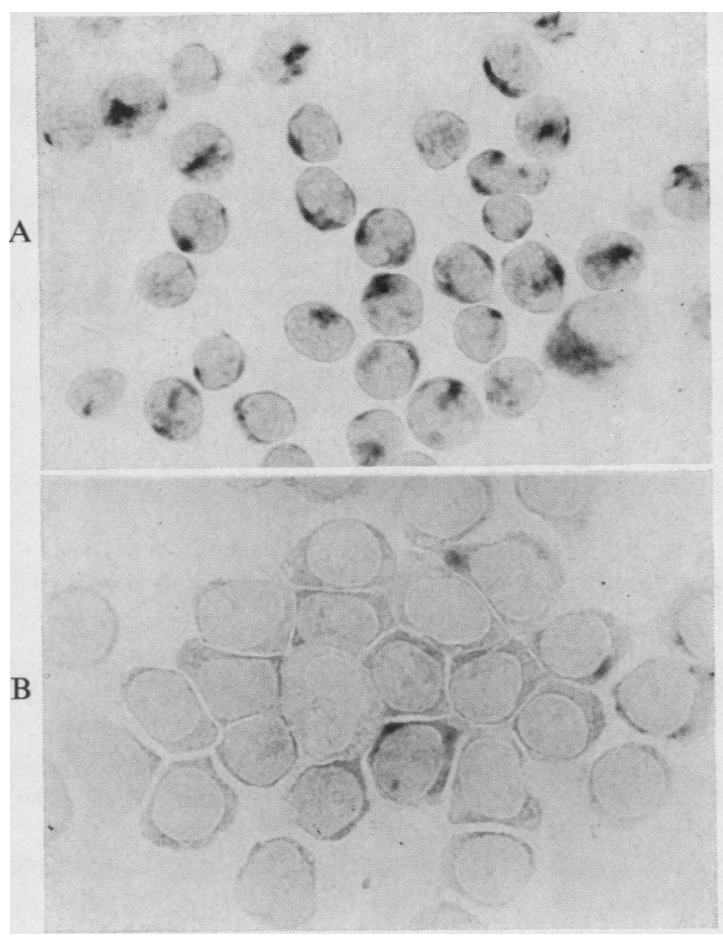

Fig 1 Acid phosphatase reaction in buffy coat preparations.

A T-prolymphocytic leukaemia; the majority of cells are strongly positive, with the reaction localized to $a$ small paranuclear area $(1200 \times)$.

B B-prolymphocytic leukaemia; one cell moderately positive and three weakly positive; the rest are negative $(1400 \times)$.

PAS reaction was strongly positive in more than $40 \%$ of the leukaemic blasts in the form of numerous coarse granules or blocks (table I).

\section{Discussion}

Our findings suggest that in the leukaemic state Band T-derived lymphoid cells can be differentiated according to their cytochemical profile. The PAS positivity in these cells is diastase-sensitive and therefore represents their cytoplasmic glycogen content while acid phosphatase is a lysosomal enzyme not related to the synthesis or degradation of glycogen. It has long been known that the glycogen content in the lymphocytes in chronic lymphocytic leukaemia is higher than in normal blood (Astaldi and Verga, 1957; Quaglino and Hayhoe, 1959), but this has not hitherto been associated with the fact that the

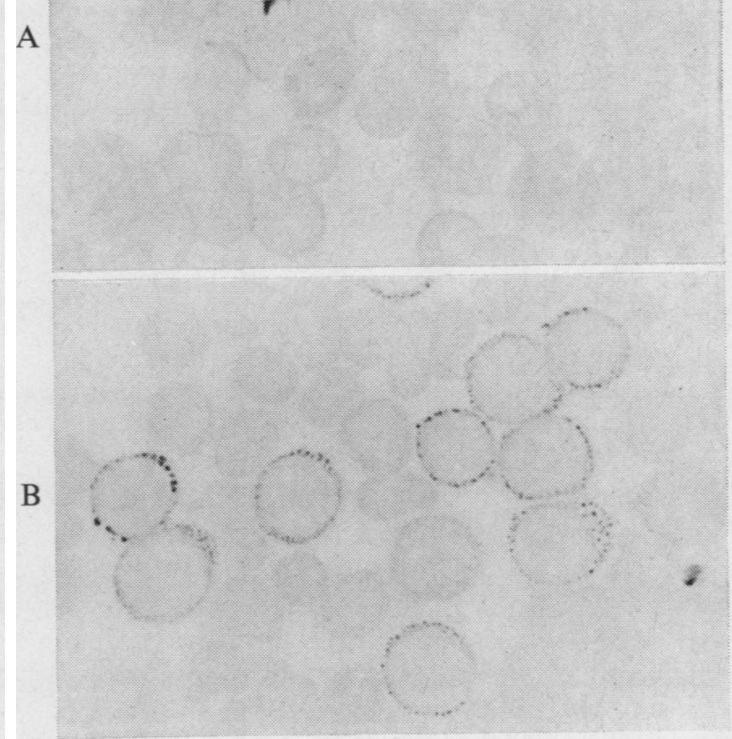

Fig 2 PAS reaction in peripheral blood films.

A T-prolymphocytic leukaemia; all lymphoid cells are negative; only one monocyte shows $P A S$ positivity $(1400 \times)$.

B B-prolymphocytic leukaemia; the majority of lymphocytes are positive with moderate to coarse granules $(1400 \times)$.

majority of the blood lymphocytes in chronic lymphocytic leukaemia are B cells. A relationship between PAS positivity and B-cell lymphomas was suggested by Stein, Lennert, and Parwaresch (1972). They have reported a higher incidence of PASpositive cytoplasmic inclusions (diastase-resistant) in histological sections of malignant lymphomas of B-cell type. As our findings refer to cytoplasmic glycogen in leukaemic lymphocytes in films, the relationship between their findings and ours is not clear and it may be purely coincidental.

The acid phosphatase reaction has also been studied in lymphoproliferative disorders, but no definite pattern established, mainly because of the relative rarity of the T-cell disorders. $\mathrm{Li}, \mathrm{Yam}$, and Lam (1970) and Douglas, Cohnen, König, and Brittinger (1973) reported a decrease in acid phosphatase activity in lymphocytes in chronic lympho- 
cytic leukaemia, which our work confirms. An increase in acid phosphatase in T-cell leukaemias has not been previously reported. It was known, however, that the lymphoid cells of infectious mononucleosis, now considered to be T-lymphocytes (Sheldon, Papamichail, Hemsted, and Holborow, 1973), and the lymphocytes transformed with phytohaemagglutinin (PHA), which are also thought to be of T-cell type, have a high acid phosphatase content (Li et al, 1970). Furthermore, Tamaoki and Essner (1969), in elegant histochemical studies in man and various rodents, demonstrated acid phosphatase and $\beta$-glucuronidase activity in the T-lymphocyte-rich areas of lymph nodes and spleen while this activity was absent in the B-lymphocyte areas, such as the germinalcentres. $\beta$-Glucuronidase, another lysosomal enzyme, has also been reported to be consistently low in patients with chronic lymphocytic leukaemia (Zittoun, Cadiou, Dao, Blanc, and Bousser, 1973; Flandrin and Daniel, 1974) and high in the cells of Sézary's reticulosis which are also considered to be of T-cell nature (Flandrin and Daniel, 1974). The presence of acid phosphatase in the cells from our T-cell patients was unrelated to the degree of cell maturity, T-prolymphocytes and T-lymphoblasts had a similar strongly positive pattern.

Of special interest was the finding of a tartrateresistant acid phosphatase in some of the prolymphocytes in the two cases of B-cell prolymphocytic leukaemia studied. This property is characteristic of the enzyme present in the 'hairy' cells of leukaemic reticuloendotheliosis (Yam et al, 1971), a lymphoproliferative disorder also thought to be of B-cell type (Catovsky, Pettit, Galetto, Okos, and Galton, 1974).

We do not know whether normal $B$ and $T$ lymphocytes would react in the same way as their leukaemic counterparts. This may be so for the acid phosphatase, as discussed above. We tried to clarify this point by performing the PAS reaction on cytocentrifuge slides of sheep red cells and $C_{3}$ rosettes, but the results were not easy to interpret. This was probably due to the rapid changes in glycogen content which occur during incubation. It is known that PHA stimulation will cause a marked increase in the glycogen content, during the first 24-48 hours, in lymphocytes undergoing blast transformation (Quaglino, Hayhoe, and Flemans, 1962); this phenomenon was seen to an even greater extent in our only case of T-cell prolymphocytic leukaemia after three days' culture with PHA.

The most useful application of our findings may be to facilitate the recognition of a distinct $T$-cell variant of acute lymphoblastic leukaemia (Catovsky et al, 1974). This may be important, as leukaemic cells in suspension may not always be readily avail- able for study while the cytochemical tests can be performed even with some delay on blood or bone marrow slides. In addition, and not surprisingly, the results with the immunological markers do not always give consistent results in leukaemic cells. For example, the blast cells in case 3 did not form rosettes with sheep red cells but did transform with PHA; similarly, the cells in one of the T-cell acute lymphoblastic leukaemia cases reported by Kersey, Sabad, Gajl-Peczalska, Hallgren, Yunis, and Nesbit (1973) did not form rosettes with sheep red cells but were positive when tested with an anti-T antiserum.

For the recognition of T-lymphoblastic leukaemia, a positive acid phosphatase reaction and a weak or negative PAS reaction may be significant. The acid phosphatase was positive in the paranuclear area in the majority of leukaemic cells of the four T-cell leukaemias studied; this reaction was not seen in the four cases of non-T-cell acute lymphoblastic leukaemia. On the other hand, the PAS reaction alone may not help to distinguish either type of acute lymphoblastic leukaemia. Although the results in our four non-T cases were similar to those considered typical of acute lymphoblastic leukaemia, one of our T-lymphoblastic patients (case 2) studied during a relapse had also, at the time of presentation, $30 \%$ of blasts with PAS-positive blocks. Moreover $40 \%$ of T-cells in a case of 'Sternberg sarcoma' had coarse granules or blocks of PAS positivity (Smith, Barker, Clein, and Collins, 1973).

Humphrey, Nesbit, and Brunning (1974) have recently reported a correlation between high leucocyte counts in acute lymphoblastic leukaemia and low PAS scores. Löffler (1973), on the other hand, has recognized a group within the PAS-positive leukaemias (acute lymphoblastic) in which the cells have less PAS-positive material and a distinct acid phosphatase positivity. The patients concerned had marked enlargement of the lymph nodes and the spleen, high leucocyte counts, and a poor response to treatment; one adult probably had thymic enlargement. These are features which we have associated with the T-lymphoblastic variant of acute lymphoblastic leukaemia which, as distinct from its more common form, seems to be characterized by a more aggressive clinical course (Catovsky et al, 1974). A similar conclusion was suggested by Borella and Sen (1973). The clinical and laboratory features of both types of acute lymphoblastic anaemia in our series are shown in table $I$. The $T$-cell cases presented with considerably higher leucocyte counts and more marked physical signs than the non-T cases. Meningeal leukaemia was an early complication in two, but the third has been followed only for one month. A combination of cytochemical and immunological studies in a larger series of patients with 
acute lymphoblastic leukaemia may provide more conclusive evidence of the distinct features that we are suggesting help to distinguish the $T$ from the non- $T$ variant of the disease.

We wish to thank Professor J. V. Dacie for his continuous advice and encouragement; Dr P. Roberts for referring case 3; and $\mathrm{Mr} \mathrm{W}$. Hinkes for the photomicrographs.

\section{References}

Astaldi, G., and Verga, L. (1957). The glycogen content of the cells of lymphatic leukaemia. Acta haemat. (Basel), 17, 129-135.

Borella, L., and Sen, Luisa (1973). T cell surface markers on lymphoblasts from acute lymphocytic leukemia. J. Immunol., 111, 1257-1260.

Catovsky, D., Goldman, J. M., Okos, A., Frisch, B., and Galton, D. A. G. (1974). T-lymphoblastic leukaemia, a distinct variant of acute leukaemia. Brit. med. J., 2, 643-646.

Catovsky, D., Pettit, J. E., Galetto, J., Okos, A., and Galton, D. A. G. (1974). The B-lymphocyte nature of the hairy cell of leukaemic reticuloendotheliosis. Brit. J. Haemat., 26, 29-37.

Dacie, J. V., and Lewis, S. M. (1970). Practical Haematology, 4th ed., p. 93. Churchill, London.

Dickler, H. B., and Kunkel, H. G. (1972). Interaction of aggregated $\gamma$-globulin with B lymphocytes. J. exp. Med., 136, 191-196.

Douglas, S. D., Cohnen, G., König, E., and Brittinger, G. (1973). Lymphocyte lysosomes and lysosomal enzymes in chronic lymphocytic leukaemia. Blood, 41, 511-518.

Flandrin, G., and Daniel, M. T. (1974). $\beta$-glucuronidase activity in Sezary cells. Scand. J. Haemat., 12, 23-31.

Galton, D. A. G., Goldman, J. M., Wiltshaw, E., Catovsky, D., Henry, K., and Goldenberg, C. J. (1974). Prolymphocytic leukaemia. Brit. J. Haemat., 27, 7-23.

Goldberg, A. F., and Barka, T. (1962). Acid phosphatase activity in human blood cells. Nature (Lond.), 195, 297.

Humphrey, G. B., Nesbit, M. E., and Brunning, R. D. (1974). Prognostic value of the Periodic Acid-Schiff (PAS) reaction in acute lymphoblastic leukemia. Amer. J. Clin. Path., 61, 393397.

Kersey, J. H Sabad, A., Gajl-Peczalska, K., Hallgren, Helen M., Yunis, E. J., and Nesbit, M. E. (1973). Acute lymphoblastic leukemic cells with $\mathbf{T}$ (thymus-derived) lymphocyte markers. Science, 182, 1355-56.
Li, C. Y., Yam, L. T., and Lam, K. W. (1970). Acid phosphatase isoenzyme in human leukocytes in normal and pathological conditions. J. Histochem. Cytochem., 18, 473-481.

Löffler, H. (1973). Biochemical properties of leukemic blast cells revealed by cytochemical methods: their relation to prognosis. In Workshop on Prognostic Factors in Human Acute Leukemia. Schloss Reisensburg, Ulm.

Mehrishi, J. N., and Zeiller, K. (1974). T and B lymphocytes: striking differences in surface membranes. Brit. med. J., 1, 360-362.

Papamichail, M., Brown, J. C., and Holborow, E. J. (1971). Immunoglobulins on the surface of human lymphocytes. Lancet, 2, 850-852.

Pepys, M. B., and Butterworth, A. E. (1974). Inhibition by $C_{3}$ fragments of $\mathrm{C}_{3}$-dependent rosette formation and antigen-induced lymphocyte transformation. Clin. exp. Immunol., in press.

Polliack, A., Lampen, N., Clarkson, B. D., De Harven, E., Bentwich, Z., Siegal, F. P., and Kunkel, H. G. (1973). Identification of human $B$ and $T$ lymphocytes by scanning electron microscopy. J. exp. Med., 138, 607-624.

Quaglino, D., and Hayhoe, F. G. J. (1959). Observations on the periodic acid-Schiff reaction in lymphoproliferative diseases. $J$. Path. Bact., 78, 521-532.

Quaglino, D., Hayhoe, F. G. J., and Flemans, R. (1962). Cytochemical observations on the effect of phytohaemagglutinin in short-term tissue cultures. Nature (Lond.), 196, 338-340.

Sheldon, P. J., Papamichail, M., Hemsted, E. H., and Holborow, E. J. (1973). Thymic origin of atypical lymphoid cells in infectious mononucleosis. Lancet, 1, 1153-1155.

Smith, J. L., Barker, C. R., Clein, G. P., and Collins, R. D. (1973). Characterisation of malignant mediastinal lymphoid neoplasm (Sternberg sarcoma) as thymic in origin. Lancet, 1, 74-77.

Stein, H., Lennert, K., and Parwaresch, M. R. (1972). Malignant lymphomas of B-cell type. Lancet, 2, 855-857.

Tamaoki, N., and Essner, E. (1969). Distribution of acid phosphatase, $\beta$-glucuronidase and $\mathbf{N}$-acetyl- $\beta$-glucosaminidase activities in lymphocytes of lymphatic tissues of man and rodents. J. Histochem. Cytochem., 17, 238-243.

Transplantation Reviews (1973). T and B lymphocytes in humans. Vol. 16.

Wybran, J., Chantler, S., and Fudenberg, H. H. (1973). Isolation of normal $\mathrm{T}$ cells in chronic lymphatic leukaemia. Lancet, 1 , 126-129.

Yam, L. T., Li, C. Y., and Lam, K. W. (1971). Tartrate-resistant acid phosphatase isoenzyme in the reticulum cells of leukemic reticuloendotheliosis. New Engl. J. Med., 284, 357-360.

Zittoun, R., Cadiou, M., Dao, C., Blanc, J. M., and Bousser, J. (1973). Lymphocytic beta-glucuronidase in the lymphoproliferative syndromes. Biomedicine, 18, 515-520. 